\title{
Design of Catamaran Ship Using Solar Power
}

Ozi Ramadhan, Syahril, Hendri Nurdin, and Purwantono

Jurusan Teknik Mesin, Fakultas Teknik, Universitas Negeri Padang, Indonesia

\begin{tabular}{|c|c|}
\hline Article Info & ABSTRACT \\
\hline Article history: & $\begin{array}{l}\text { Solar power is a renewable energy that can replace oil fuel as the } \\
\text { main energy of the ship. The use of fuel oil can worsen the }\end{array}$ \\
\hline Received Jan $17^{\text {th }}, 2018$ & environment in the Maninjau lake tourism area. This paper aims to \\
\hline Revised March $18^{\text {th }}, 2018$ & develop a ship propulsion design using solar power with the main \\
\hline Accepted May $15^{\text {th }}, 2019$ & size of the WL bilge Length $367.33 \mathrm{~cm}$, Width $(B) 170 \mathrm{~cm}$, Height $(H)$ \\
\hline & $70 \mathrm{~cm}$, Draught (T) $30.7 \mathrm{~cm}$. To produce the power needed at a speed \\
\hline Keywords: & $\begin{array}{l}\text { of } 6 \text { knots, using the method of theoretical analysis by counting, total } \\
\text { energy and solar panels to convert sunlight into electrical energy. }\end{array}$ \\
\hline Ship Drive & The result of calculating the total energy needed to reach 6 knots is \\
\hline Solar power & $0.932 \mathrm{~kW}$. The solar panels needed to produce the power are 4 pieces \\
\hline Catamarans & with a capacity of $100 \mathrm{Wp}$. This system does not use an inverter \\
\hline $\begin{array}{l}\text { Solar Cells } \\
\text { Cruise Ship }\end{array}$ & because it uses a DC electric motor as a vessel driver. The design of \\
\hline Cruise snip & $\begin{array}{l}\text { a solar-powered boat can be an option for the community as an } \\
\text { environmentally friendly tourist ship without fuel. }\end{array}$ \\
\hline
\end{tabular}

Corresponding Author:

Ozi Ramadhan,

Jurusan Teknik Mesin, Fakultas Teknik, Universitas Negeri Padang

Jln. Prof. Dr. Hamka Air Tawar, Padang (25131), Sumatera Barat, Indonesia

Email: ramadhanozi70@gmail.com

\section{INTRODUCTION}

The ship is a complex vehicle that is required to be able to operate and survive with high durability over a long period of time in a changing environment. Tourist boats are vessels used to support tourism activities for tourists [1]. On the Maninjau lake tour boat uses fossil fuels as the main energy driving fuel motor. As stated [2] Dependence on fossil fuels can cause a serious threat, namely: (1) depleted petroleum reserves (2) unstable oil production causes oil prices to change frequently. This causes the environment to be worse due to air pollution caused by the fuel from the motorbike. The ship that will be planned uses the drive of solar power as the main energy. Solar power is a renewable energy that can replace oil fuel as the main energy of the ship. The advantages of this system are that the energy obtained is free, does not cause pollution, does not require fuel to move the ship, easier maintenance. According to [3] "This can overcome the scarcity of fossil fuel energy and reduce air pollution, besides that also to provide added value to the tourist area".

The area of Indonesia has daily solar rays of 4,000-5,000 Wj / $\mathrm{m} 2$, while the average number of hours of irradiation is between 4 and 8 hours [4]. Electricity generation can be used in two ways, directly with photovoltaic and indirectly by concentrating solar energy. In this study using solar energy with photovoltaics. The following is an overview of the structure of solar panels:

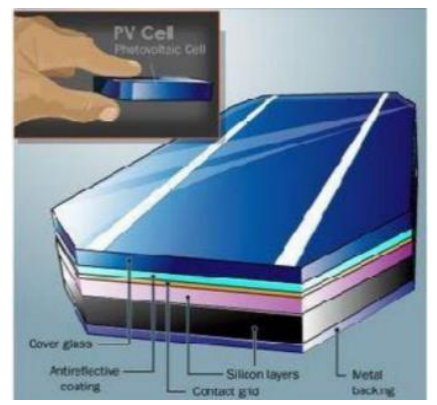

Figure 2 : Solar Cell Structure [5] 
In sunlight there are various electromagnetic waves, it is expected that solar panels can absorb as much radiation as possible from sunlight [6]. When the solar cell absorbs sunlight, free electrons and holes make a positive/negative connection, and when connected to a DC load, the electric current will flow to that load.

\section{METHOD}

This paper is the development of ship propulsion that uses solar power. Obstacle value produced at a speed of 6 knots is obtained 301, $08 \mathrm{~N}$. The speed of 6 knots is taken because considering the energy to be produced by the solar cell system is not constant and also the surface area needed for solar panels also needs to be considered. So with variable speed and obstacles, it can be seen the amount of energy needed to move the ship. The power output needed as vessel propulsion will be used as a parameter in calculating the number of solar panels and supporting components used in this system.

\subsection{Research Objects}

The research object used is a ship with a flat catamaran hull inside. The following is the gastric form that will be used as the object of research.

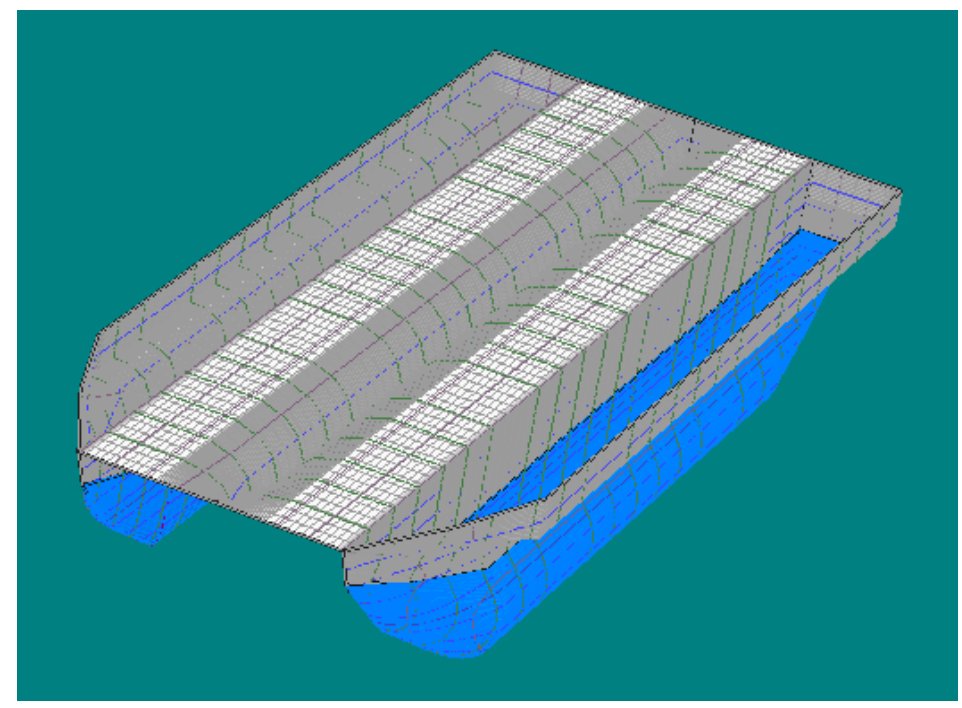

Fig. 3. Flat Inside Inside Catamaran

The following are the dimensions of a flat inside catamaran ship as follows:

Table 1. The dimension of Gastric Katamaran

\begin{tabular}{clrr}
\hline No & \multicolumn{1}{c}{ Parameter } & Value & \multicolumn{1}{c}{ Unit } \\
\hline 1 & Displaced & 448679,63 & $\mathrm{~cm}^{\wedge} 3$ \\
2 & WL Length & 367,33 & $\mathrm{~cm}$ \\
3 & Beam (B) & 170 & $\mathrm{~cm}$ \\
4 & Drought (H) & 70 & $\mathrm{~cm}$ \\
5 & Draft (T) & 30,7 & $\mathrm{~cm}$ \\
10 & Prismatic Coeff. (Cp) & 0,805 & - \\
11 & Block Coeff. (Cb) & 0,779 & - \\
12 & Max Sect. Area Coeff. (Cm) & 0,967 & - \\
13 & Water. Area Coeff. (Cup) & 0,939 & - \\
\hline
\end{tabular}

\subsection{Data Analysis Techniques}

\subsubsection{Need Power}

The total energy is the power needed to move the ship with engine capacity according to the size of the ship. To calculate total energy you can use the formula from [7] as follows: 


\subsubsection{Machine Selection}

$$
E H P=R t \times V S
$$

The driving motor is the engine which is the main driving source of the booster system [8]. In the selection of machines used as propulsion of the ship is an electric outboard engine with a capacity that will be determined from the results of the calculation of total energy.

\subsubsection{Calculating the Number of Panels}

The number of panels referred to here is the amount of use of solar panels needed to be able to drive the electric drive engine. for the number of solar panels can be determined by equation [4]:

$$
\text { Number of Solar Panels }=\frac{\text { Total Power Requirement (Watts/Hours) }}{\text { Solar Cell Panel Capacity (Watts) } \times \text { Solar Radiation (Hours) }}
$$

\subsubsection{Determination of component types}

The components used in the design of the propulsion of this ship are:

\subsubsection{Combiner}

Combiner functions as a safety PV that contains $\mathrm{CB}$, fuse and as a place for combining electric current from PV before continuing to the charge controller and battery [9]. This will save the use of cable components. Because the cable that is usually used as an intermediary from the panel to the Solar charge controller can be reduced by using a combiner.

\subsubsection{Solar charge controller}

This tool serves to regulate the voltage and current released from the solar module, do the battery charging process, prevent the battery from overcharging, also control the discharge process [10].

\subsubsection{Battery}

Battery functions as a storage of energy produced from solar panels. The energy produced by solar panels will be stored before use. This avoids power shortages when the system is used and can damage the battery when the battery empties during operation. So this can be anticipated by calculating the number of batteries used by the formula [4] as follows:

$$
\text { Minimum battery amount }=\frac{2 \times \text { Total power needed }}{\text { the battery used }(\text { Volt } \times \mathrm{Ah})}
$$

To determine the battery charging rate the time needed to fill the battery in an empty state until it is fully charged can be calculated by equation [11] as follows:

$$
\mathrm{T}=\frac{2 \mathrm{x} \text { battery used (Volt } \mathrm{x} \text { Ah) }}{\text { Solar Cell Panel Capacity (Watt) }}
$$

\subsection{Draft scheme for a solar-powered ship propulsion system}

The ship's propulsion system uses solar power in the form of a series of images in which all the components have been combined into a series.

\section{RESULTS AND DISCUSSION}

\subsection{The power needed to move the ship}

The theoretical calculation results of the required power are $0.932 \mathrm{kWatt}$. The results of the power obtained will be a reference as the engine selection will be used to drive the ship. In the selection of the engine, the required power is needed because the engine capacity used will have an impact on the engine's thrust against the ship. 


\subsection{Determining the Machine Type}

The machine that is used as the propulsion of the ship is an electric outboard engine with a capacity of 2 hp. On this machine, there are 5 advanced modes and 2 reverse modes so you can choose the speed as desired. Equipped with a battery indicator so you can set the route correctly. The rotor support pole is made of stainless steel material so it is very strong. This type of machine has become an option as a driver of the ship because with the specifications as in table 2 this machine can produce thrust with a capacity of 2 HP. Then this machine will be used as much as 1 piece as the driver of the ship. The following machine specifications are used:

Table 2. Specifications of Electric Vessel Machines

\begin{tabular}{ll}
\hline Type & Dc - Electric \\
Power & $540-660$ Watt \\
Voltage & 12 Voltage \\
Height & $15 \mathrm{gr}$ \\
\hline
\end{tabular}

\subsection{Number of Solar Panels}

The calculation results can be the number of panels 3,728 . So, the solar panels to be used will have 4 solar panels with a capacity of $100 \mathrm{WP}$. The type of solar panel used is the type of polycrystal. In this calculation, the researchers assume the duration of use of this system is 2 hours. This type of panel is used because the type of polycrystal has the advantage of being able to absorb light when it is cloudy. This is a consideration in the selection of solar panels. Solar panels besides absorbing sunlight can also be used as a protective/roofing vessel. The total area of the solar panel is $4.2 \mathrm{~m} 2$. This area can be determined by the length of the solar panel $2.4 \mathrm{~m}$ and the width of $1.5 \mathrm{~m}$ as shown in Figure 4.

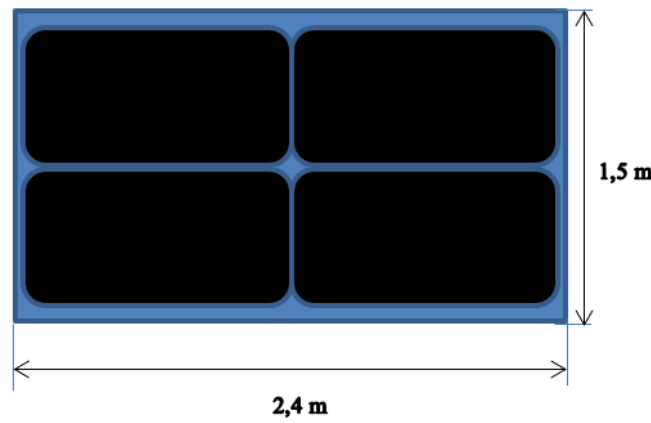

Fig. 4. Solar Panel Area

Table 3. Solar Panel Specifications

\begin{tabular}{ll}
\hline Specification & Information \\
\hline Max. Power (Pmax) & $100 \mathrm{~W}$ \\
Max. Power Voltage (Vmp) & $17.6 \mathrm{~V}$ \\
Max. Power Current (Imp) & $5.69 \mathrm{~A}$ \\
Open Circuit Voltage (Voc) & $22.0 \mathrm{~V}$ \\
Short Circuit Current (Isc) & $6.11 \mathrm{~A}$ \\
Tolerance & $\pm 3 \%$ \\
Nominal Operating Cell Temp (NOCT) & $45^{\circ} \mathrm{C}$ \\
Max. System Voltage & $1000 \mathrm{VDC}$ \\
Max. Series Fuse & $10 \mathrm{~A}$ \\
Cell Technology & Poly-Si \\
Weight & $7.7 \mathrm{Kg}$ \\
Dimension & $1021 \times 70 \times 30 \mathrm{~mm}$ \\
\hline
\end{tabular}

Journal homepage: http://teknomekanik.ppj.unp.ac.id

DOI: https://doi.org/10.24036/tm.v2i2.2372 


\subsection{Components used in solar drive systems}

\subsubsection{Combiner}

In this series use the type of 4 in 1 out Quatplexser Combiner. The choice of the combiner is based on the number of panels to be combined, there are 4 solar panels, so combiner with 4 inputs is used. This can also reduce the use of connecting cables from solar panels to the solar charge controller. Because by using a combiner, the 4 panels used will be connected to the combiner and will be forwarded to the solar charge controller with 1 cable out. So it can minimize the use of cables. The following combiner specifications are used:

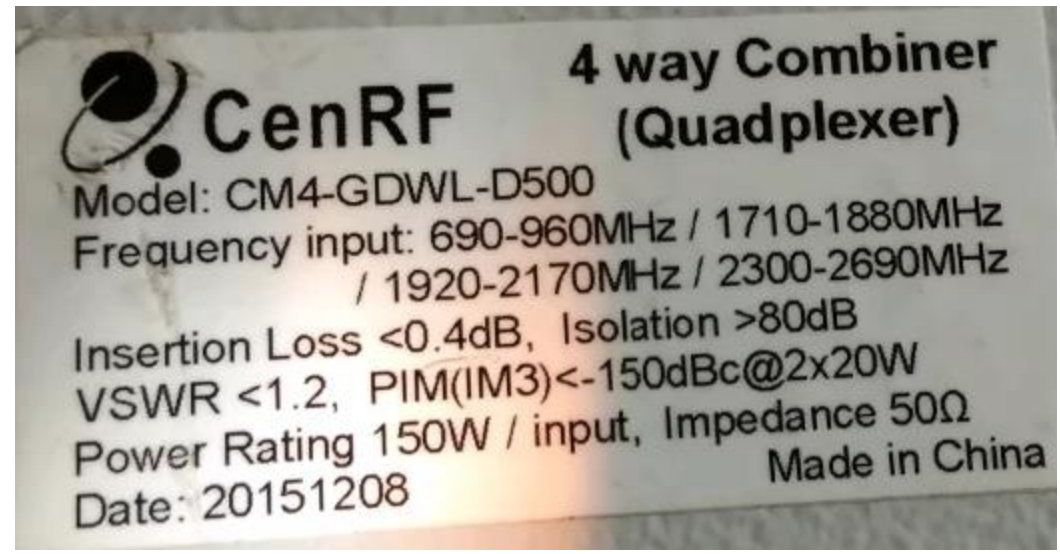

Fig. 4. Combiner specifications

\subsubsection{Battery}

The battery used is 2 YUASA N 70Z-75D31R battery. The use of 2 pieces of battery with a capacity of $12 \mathrm{v} 75 \mathrm{Ah}$ because the motor that is driven requires considerable power. It also functions as a backup energy that needs to be in an emergency. The amount of battery charging rate in an empty state takes 4.5 hours until it is fully loaded. The following battery specifications are used:

Table 5. Battery specifications

\begin{tabular}{ll}
\hline Specification & YUASA N 70Z $-75 \mathrm{D} 31 \mathrm{R}$, \\
Volt & $12 \mathrm{~V}$ \\
Capacity & $75 \mathrm{Ah}$ \\
Dimension & $173 \mathrm{x} 202 \mathrm{~mm}$ \\
\hline
\end{tabular}

\subsubsection{Solar Charge Controller}

This circuit uses one BCU with the following specifications:

Table 5. Epsolar LS1024R BCU Specifications

\begin{tabular}{ll}
\hline Nominal System Voltage & $12 / 24 \mathrm{VDC}$ \\
Rated Battery Current & $10 \mathrm{~A}$ \\
Max. Battery Voltage & $32 \mathrm{~V}$ \\
Charge Circuit Voltage Drop & $\leq 0.26 \mathrm{~V}$ \\
Discharge Circuit Voltage Drop & $\leq 0.15 \mathrm{~V}$ \\
Overall dimension & $140 \times 65 \times 34 \mathrm{~mm}$ \\
Net weight & $0.15 \mathrm{~kg}$ \\
\hline
\end{tabular}

\subsection{Draft scheme for a solar power ship propulsion system}

This system uses solar panels with a capacity of $100 \mathrm{WP}$, with the meaning that solar panels will be able to produce 100 watts per hour in maximum conditions. With the power needed by a motor of $0.932 \mathrm{kWatt}$, 
four solar panels are needed. The total area of solar panels needed is $4.2 \mathrm{~m} 2$. So that solar panels can be used requires a combiner and solar charge controller as a regulator of the incoming flow to the battery. After the energy is stored by the new battery, it is distributed to the motor. Charging 2 batteries with a capacity of $12 \mathrm{v}$ $75 \mathrm{Ah}$ can be filled from empty until fully charged takes 4.5 hours.

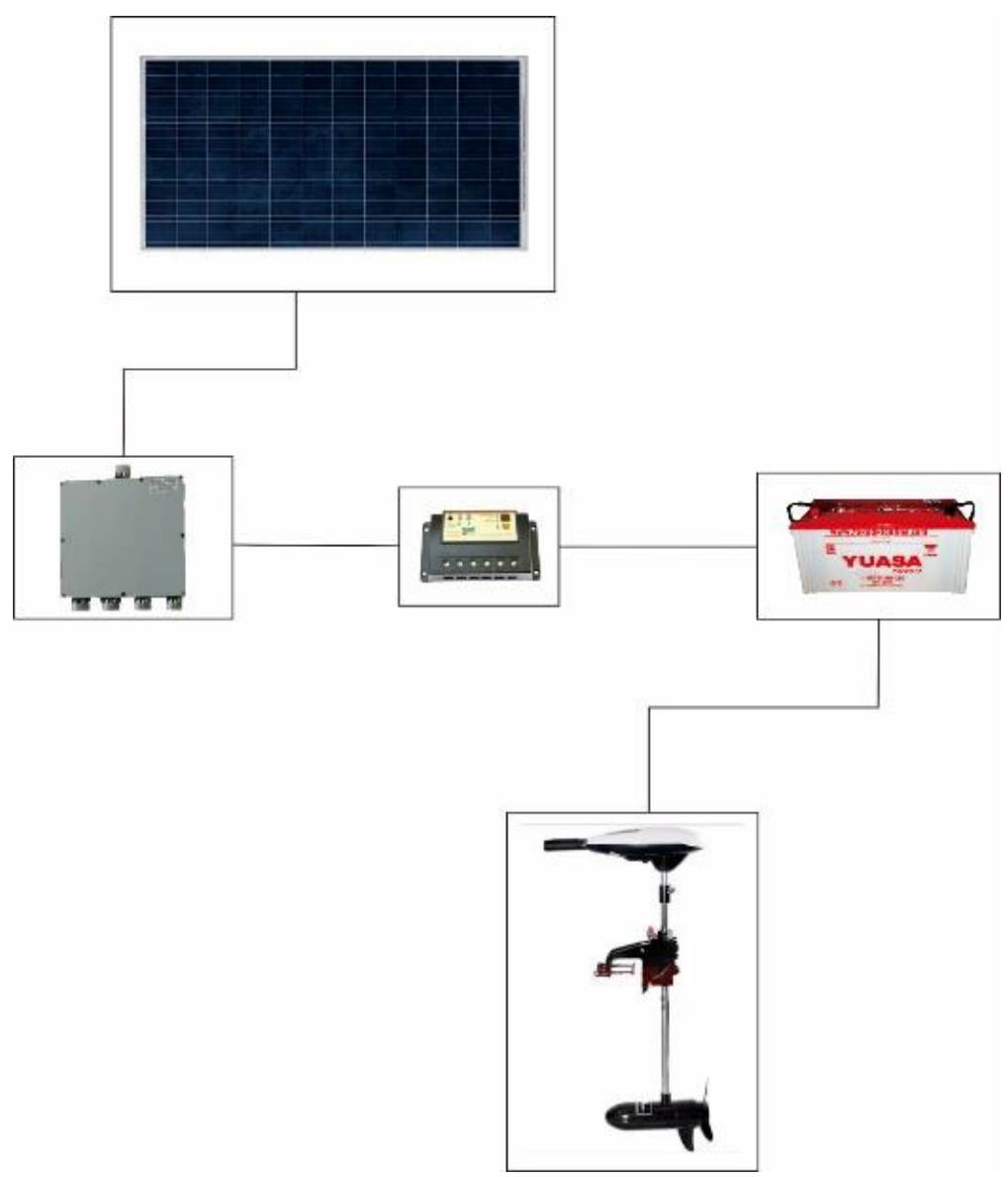

\section{CONCLUSION}

Fig. 5. Schematic of a Solar Drive System

The development of solar-powered propulsion of ships can be concluded that using the scheme will help in designing shipbuilders. This is seen from the use of energy on ships that they no longer use fossil fuels but with solar power. In this design do not use an inverter because the energy from solar panels that have a DC current can be channelled directly to the motor with a DC current. This drive system also does not require many cables because 4-panel currents can be combined with combiner and output into 1 output after which it can proceed to the solar charge controller.

\section{REFERENCES}

[1] D. Erwin, A. A. Berlian, and B. Untung, "Studi Perancangan Glass Bottom Catamaran Untuk Menunjang Objek Wisata Di Kawasan Anak Gunung Krakatau,” pp. 1-10, 2012.

[2] Arwizet, "Mesin destilasi pengolahan sampah plastik menjadi bahan bakar minyak menggunakan kondensor bertingkat dan pendingin kompresi uap," vol. 17, no. 2, 2017.

[3] Rahayu M.B., “Jurnal Teknik Mesin, Volume 6, Nomor 1, Tahun 2017,” vol. 6, no. 6, pp. 37-44, 2017.

[4] Zulkifly A. Y. and Andi H.S., "Perancangan Kapal Wisata Dengan Tenaga Surya Sebagai Energi Alternatif Penggerak Propeller," vol. 5, pp. 978-979, 2011.

[5] Nora Aditiyan, "Karakterisasi Panel Surya Model SR-156P-100 Berdasarkan Intensitas Cahaya Matahari," 2015.

[6] Krismadinata, Miftahul, Ainul .H, Habibullah, Remon. L, and Syahril, "Sistem Akusisi Data Nirkabel Karakteristik Modul Surya," 2017. 
[7] Ari W.B.S., Andi T., and Fazjeri U., "Perancangan Kapal Tongkang Sebagai Penyebrangan Masyarakat Di Sungai Bengawan Solo , Desa Jimbung Kabupaten Blora - Desa Kiringan Kabupaten Bojonegoro," KAPAL J. Ilmu Pengetah. dan Teknol. Kelaut., vol. 9, no. 1, 2012.

[8] Ari W.B.S. and Reza S.A., "Pemanfaatan Energi Alternatif Gas Alam Terkompresi Sebagai Bahan Bakar Mesin Penggerak Kapal Nelayan Tradisional," KAPAL J. Ilmu Pengetah. dan Teknol. Kelaut., vol. 9, pp. 1-4, 2013.

[9] Abdul H., Zainal A., Saddam H., and Rahmat U., “Analisa Pembangkit Listrik Tenaga Surya Pulau Balang Lompo," vol. 14, pp. 6-12, 2017.

[10] Hassan A.K and Saad P., "Technological review on solar PV in Pakistan: Scope, practices and recommendations for optimized system design," Renew. Sustain. Energy Rev., vol. 23, pp. 147-154, 2013.

[11] Sudiyono dan Bambang Antoko, "Perancangan dan Pembuatan Kapal Wisata dengan Motor Generator Listrik Tenaga Surya Sebagai Energi Alternatif Penggerak Propeler," Tek. Mesin, vol. 10, pp. 52-61, 2008.

\section{NOMENCLATURE}

$\begin{array}{ll}\text { EHP } & =\text { Energy Hourse Power } \\ \text { Rt } & =\text { Resistance total } \\ \text { Vs } & =\text { Speed } \\ \mathrm{T} & =\text { Time }\end{array}$

